\title{
The regenerative flatworm Macrostomum lignano, a model organism with high experimental potential
}

\author{
STIJN MOUTON", JAKUB WUDARSKI", MAGDA GRUDNIEWSKA and EUGENE BEREZIKOV* \\ European Research Institute for the Biology of Ageing, University of Groningen, \\ University Medical Center Groningen, Groningen, The Netherlands
}

\begin{abstract}
Understanding the process of regeneration has been one of the longstanding scientific aims, from a fundamental biological perspective, as well as within the applied context of regenerative medicine. Because regeneration competence varies greatly between organisms, it is essential to investigate different experimental animals. The free-living marine flatworm Macrostomum lignano is a rising model organism for this type of research, and its power stems from a unique set of biological properties combined with amenability to experimental manipulation. The biological properties of interest include production of single-cell fertilized eggs, a transparent body, small size, short generation time, ease of culture, the presence of a pluripotent stem cell population, and a large regeneration competence. These features sparked the development of molecular tools and resources for this animal, including high-quality genome and transcriptome assemblies, gene knockdown, in situ hybridization, and transgenesis. Importantly, M. lignano is currently the only flatworm species for which transgenesis methods are established. This review summarizes biological features of $M$. lignano and recent technological advances towards experimentation with this animal. In addition, we discuss the experimental potential of this model organism for different research questions related to regeneration and stem cell biology.
\end{abstract}

KEY WORDS: flatworm, Macrostomum, regeneration, neoblast, transgenesis

\section{Introduction}

Regeneration of missing or damaged body parts and tissues is an intricate multicellular process. The ability to regenerate is broadly present within the Metazoa but its extent shows large variation (SánchezAlvarado, 2000; Bely and Nyberg, 2010; Tanaka and Reddien, 2011; Li et al., 2015). Animals like Hydra can regenerate the whole body (Bosch, 2007), while in human regeneration is limited to certain tissues and organs, such as the liver (Michalopoulos and DeFrances, 1997). Despite the longstanding fascination of scientists for regeneration and the promise of enhancing human tissue and organ repair by regenerative medicine, the regenerative process is still poorly understood (Rosenthal and Badylak, 2016). To advance developments in regenerative medicine, it is important to study regeneration in an evolutionary context and to increase our understanding of the basic biology underlying tissue repair (Rosenthal and Badylak, 2016). Therefore, scientists study the molecular and cellular mechanisms of regeneration in a wide variety of experimental animals, such as Hydra, flatworms, crustaceans, amphibians and zebrafish (Tanaka and Reddien, 2011; Li et al., 2015).

In this concise review we focus on the flatworm Macrostomum lignano. As a representative of the Macrostomorpha, M. lignano is a basal member of the flatworms (Platyhelminthes), while the well-known models Schmidtea mediterranea and Dugesia japonica are members of the more derived clade of Tricladida (Fig. 1A). M. lignano was first brought into the laboratory in 1995 (Ladurner et al., 2005), and has since been used as a model for stem cell biology, development, regeneration, ageing, sex allocation, sperm competition, and bio-adhesion (Schärer and Ladurner, 2003; Morris et al., 2004; Egger et al., 2006; Nimeth et al., 2007; Ladurner et al., 2008; Mouton, Willems, Braeckman, et al., 2009; Willems et al., 2009; Lengerer et al., 2014; Marie-Orleach et al.,

Abbreviations used in this paper: $\mathrm{BA}$, blastomere anarchy; EC, ectolecithal egg; EN, entolecithal egg; SP, spiral cleavage.

*Address correspondence to: Eugene Berezikov. European Research Institute for the Biology of Ageing, University of Groningen, University Medical Center Gro-
ningen, Antonius Deusinglaan 1, 9713AV Groningen,The Netherlands. Tel: +31-503617300. E-mail: e.berezikov@ umcg.nl - (D) http://orcid.org/0000-0002-1145-2884

\#Note: The indicated authors contributed equally to this paper.

Submitted: 28 February, 2018; Accepted: 1 March, 2018.

ISSN: Online 1696-3547, Print 0214-6282

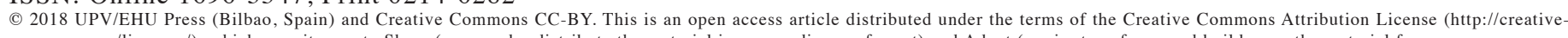

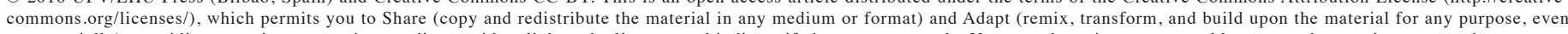

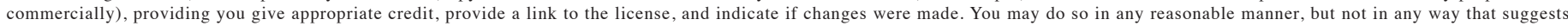
the licensor endorses you or your use. Printed in Spain 
2016; Giannakara et al., 2016). During the last years, important progress was made in the development of molecular tools for this animal, such as the establishment of transcriptome and genome assemblies, and the development of transgenic methods (Wasik et al., 2015; Grudniewska et al., 2016; Wudarski et al., 2017). Here, we describe the key aspects of the biology of M. lignano, which make it a convenient model for experimentation, discuss the recent progress of developing molecular tools and resources, and illustrate the potential of this model for research areas related to regeneration and stem cell biology.

\section{The biology of Macrostomum lignano}

The flatworm $M$. lignano is a free-living, marine species. Its natural environment is the high-tide interstitial sand fauna of beaches of the Northern Adriatic Sea, Italy (Ladurner et al., 2000; Ladurner et al., 2005). In the laboratory, the worms can be easily cultured in Petri dishes with nutrient-enriched artificial sea water $(\mathrm{f} / 2)$ at a salinity of $32 \%$. The dishes are maintained at $20^{\circ} \mathrm{C}$ and a $14 \mathrm{~h} / 10 \mathrm{~h}$ or $13 \mathrm{~h} / 11 \mathrm{~h}$ light/dark cycle, and worms

A

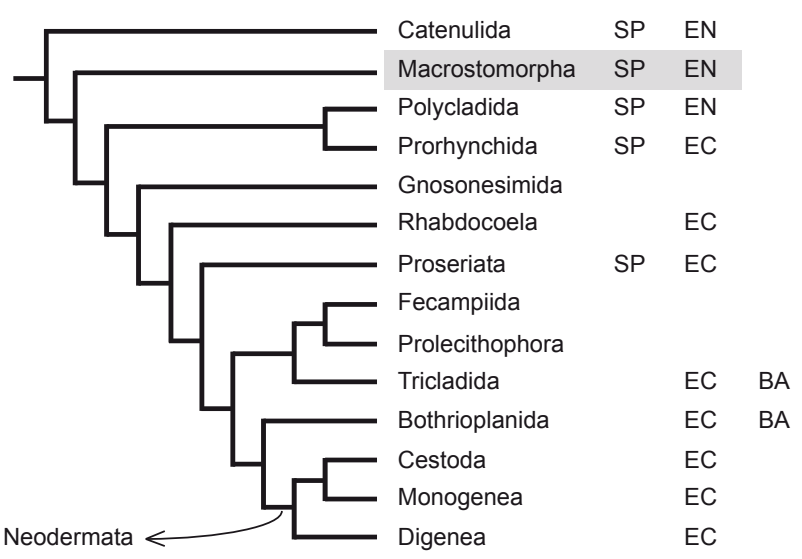

B

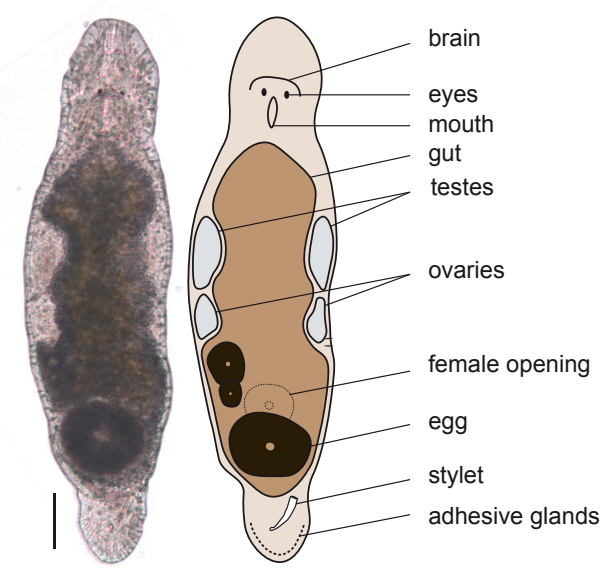

C

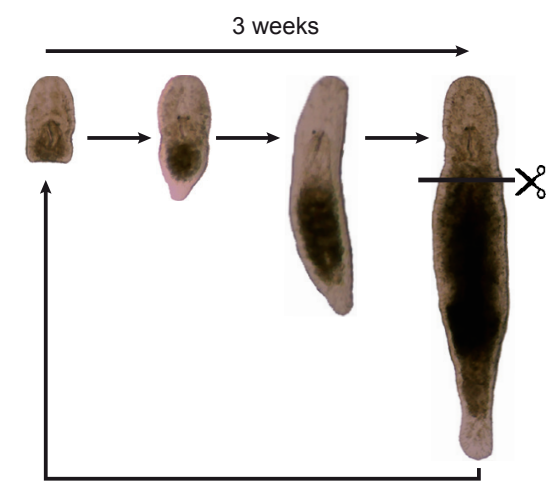

are fed ad libitum with the diatom Nitzschia curvilineata, which is grown in the same conditions (Rieger et al., 1988).

$M$. lignano is an obligatory non-self-fertilizing hermaphrodite, which reproduces exclusively in a sexual manner (Schärer and Ladurner, 2003). Mass cultures can be quickly established, as adult worms lay about one egg each day at $20^{\circ} \mathrm{C}$. The embryonic development lasts 5 days, while the total generation time is about 18 days. In contrast to planarians, which exhibit a highly derived embryogenesis, sometimes referred to as "blastomere anarchy" (Cardona et al., 2005; Cardona et al., 2006), the early embryonic cleavages of $M$. lignano are of the quartet spiral type, while in the later stages the process of "inverse epiboly" takes place, meaning that the blastomeres at the vegetal pole form an outer yolk mantle at the surface of the embryo (Morris et al., 2004). It is important to note that the eggs follow the entolecithal (archoophoran) mode of development (Fig. 1A) (Morris et al., 2006; Egger et al., 2015), making them an easy target for microinjections, as the single cell has a relatively large size of $100 \mu \mathrm{m}$ (Fig. 1B).

The morphology of $M$. lignano is described in detail (Ladurner et al., 2005; Morris et al., 2007). Defining characteristics are its small size (about $1.5 \mathrm{~mm}$ ), the presence of two pigment-cup eyes enabling light sensing, and the transparency of the complete body. Internal organs, such as the brain, gut, testes, ovaries, and developing eggs can be easily observed (Fig. 1B). The tail plate with a slightly curved stylet, representing the male reproductive organ, and adhesive glands, enabling the animal to attach and detach from most surfaces, is another morphological characteristic of Macrostomum (Lengerer et al., 2016).

The regenerative flatworms are usually perceived through planarians, which have almost unlimited regenerative capabilities. The Macrostomorpha are, however, not far behind and also have an excellent regeneration capacity when compared to most of the free-living flatworm taxa (Egger et al., 2007). Fig. 1C illustrates how an amputated head of $M$. lignano can regenerate the complete body, including the germline, within 3 weeks. M. lignano is able to regenerate missing body parts anteriorly, posteriorly, and laterally, although the presence of the region proximal to the brain, eyes and pharynx is obligatory. In other words, when cut in half, only the head-piece will regenerate and survive (Egger et al., 2006). Interestingly, in planarian species which have limited capacity of head regeneration, the regeneration deficiency can be rescued by downregulation of canonical Wnt signalling (Liu et al., 2013; Sikes and Newmark, 2013). Similarly, although the amputated tail region of $M$. lignano cannot regenerate the head under normal conditions, there is anecdotal evidence that head regeneration can be induced (Simanov et al., 2012), but further research is needed to fully unravel these mechanisms. The regenerative

\begin{abstract}
capacity after different types of amputation is
\end{abstract}
Fig. 1. Phylogeny, morphology and regeneration of Macrostomum lignano. (A) Schematic representation of the phylogeny of the flatworms (Platyhelminthes). The tree and the presence of spiral cleavage (SP) is based on Laumer et al., 2015. The presence of entolecithal (EN) or ectolecithal (EC) eggs, and blastomere anarchy (BA) is based on Egger et al., 2015. (B) Bright field image and schematic representation of an adult worm. Scale bar: $100 \mu \mathrm{m}$. (C) Regeneration cycle from a head fragment into an adult, fertile worm, of which the body can be amputated again. 
described in detail by Egger et al., (Egger et al., 2006). Interestingly, a limit of the regeneration competence of this species has not been fully identified yet. Even after 29 consecutive amputations of the body, a decline of the regeneration rate could not be observed (Egger et al., 2006). Moreover, there are reports of individuals surviving almost 60 consecutive amputations (Egger et al., 2006; Egger, 2008).

At the cellular level, the body of $M$. lignano can be described as a dynamic steady state. In total, there are about 25.000 cells and there is a high cellular turnover during homeostasis (Ladurner et al., 2000; Nimeth et al., 2002). The epidermis is an interesting example, as about one third of all cells are renewed within two weeks (Nimeth et al., 2002). As in all flatworms, the source of new cells during regeneration and homeostasis are stem cells called neoblasts (Fig. 2A,B), which are the only somatic proliferating cells in the adult body (Ladurner et al., 2000). Importantly, besides the somatic neoblasts, proliferating cells are also present in the gonads (Ladurner et al., 2000) (Fig. $2 A)$. The neoblasts are morphologically characterized as small, round cells (6-10 $\mu \mathrm{m})$ with a high nuclear:cytoplasmic ratio (Bode et al., 2006). The large nucleus has a prominent nucleolus, and the cytoplasm has few organelles limited to free ribosomes, few mitochondria, and none or very little endoplasmic reticulum (Ladurner et al., 2000; Nimeth et al., 2002; Bode et al., 2006)
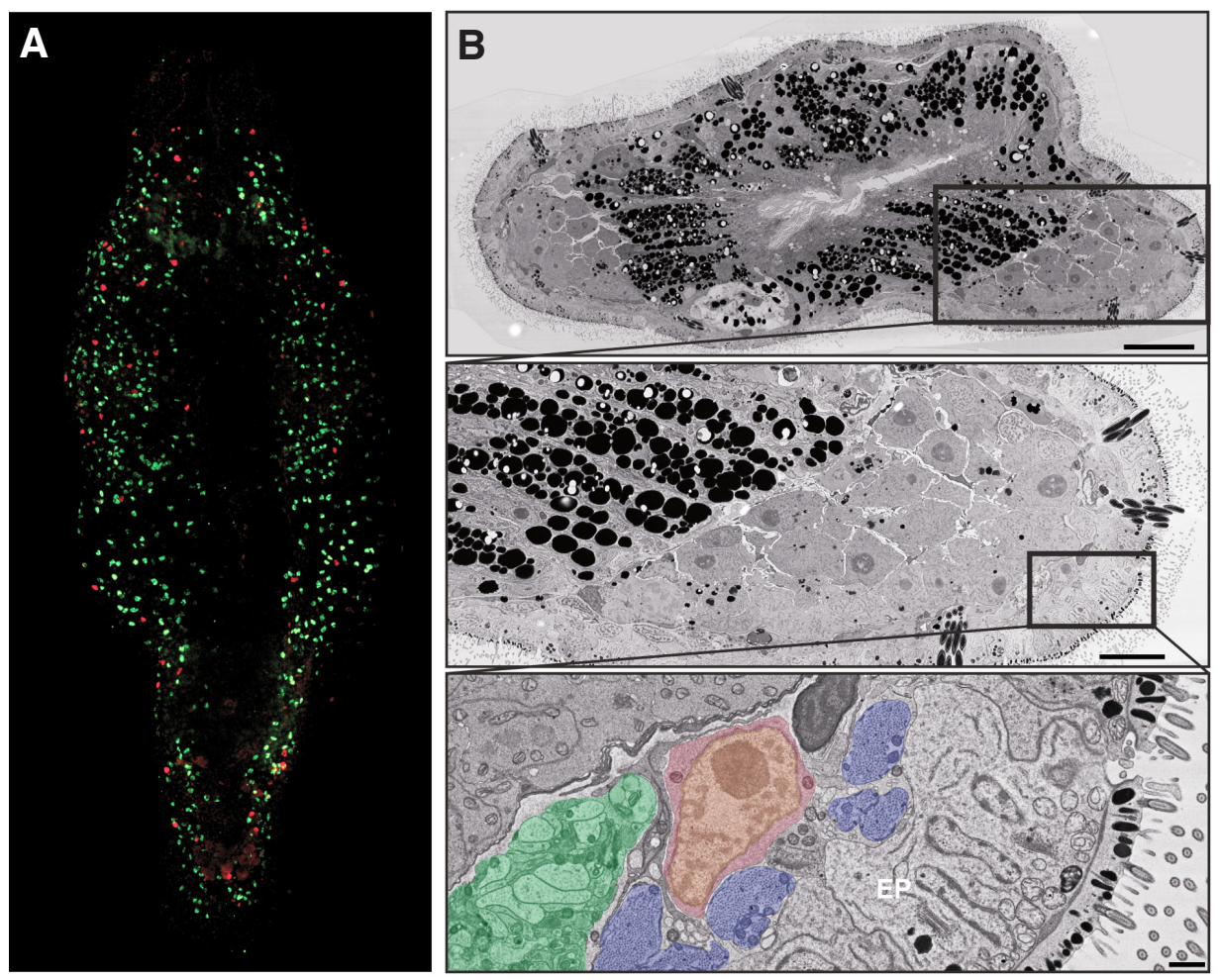

Fig. 2.The neoblast population of Macrostomum lignano. (A) Confocal projection of BrdU (green: S-phase cells) and phospho-histone H3 (red: mitotic cells) immunostaining of an adult worm. Note the bilateral pattern of the proliferating cells. (B) Nanotomy of M. lignano (Grudniewska et al., 2018). Top to bottom represents zooming in on the boxed areas, starting with a complete cross section and finishing with a detailed view illustrating the ultrastructure of a neoblast and its surrounding. The nucleus of the neoblast (orange) is characterized by patchy clumps of condensed chromatin and a large nucleolus, and is surrounded by a thin rim of cytoplasm (red). The neoblast lays in direct contact with the lateral nerve chord (green) and muscle tissue (blue). EP indicates the epidermis of the animal. Scale bars from top to bottom: $25 \mu \mathrm{m}, 10 \mu \mathrm{m}, 1 \mu \mathrm{m}$.
(Fig. 2B). A comprehensive summary of our

knowledge about the flatworm neoblast population is provided in reviews by Baguña (Baguña, 2012) and Rink (Rink, 2013). In $M$. lignano, the neoblasts are located within the parenchyma, in two bands along the lateral sides of the animal, merging in the tail plate. The typical pattern of the neoblasts can be explained by the close relation of their location to the main lateral nerve chords (Ladurner et al., 2008) (Fig. 2A). In the rostrum, the region in front of the eyes, neoblasts are absent (Ladurner et al., 2000) (Fig. 2A). It is estimated that about $6.5 \%$ of all cells are somatic neoblasts, of which $27 \%$ are in S-phase (Ladurner et al., 2000; Nimeth et al., 2004; Bode et al., 2006). The neoblast population is assumed to be actively proliferating, but there are indications that a small fraction of the population is slow cycling or quiescent (Bode et al., 2006; Verdoodt et al., 2012). The commonly used methods to visualize the neoblasts is to label cells in S-phase by means of BrdU incorporation, or to label the mitotic cells with a polyclonal antibody against phosphorylated Histone H3 (Ladurner et al., 2000; Ladurner et al., 2008). In addition, in situ hybridization can be performed to visualize the expression of piwi and vasa, which are expressed in all proliferating cells, representing both somatic neoblasts and germline cells (Pfister et al., 2007; Pfister et al., 2008; De Mulder et al., 2009). To isolate proliferating cells, a cell sorting approach based on the 4C DNA content of
Hoechst-labeled cells in the late S-, G2, and M-phase of the cell cycle is used (Grudniewska et al., 2016). The somatic neoblast population as a whole is pluripotent and able to form all cell types present in the body, including the germline. However, based on research in freshwater planarians (Van Wolfswinkel et al., 2014; Molinaro and Pearson, 2016; Zhu et al., 2016), it is assumed that the neoblasts in $M$. lignano represent a heterogeneous population of pluripotent stem cells and subsets of stem cells and progenitors of different differentiation lineages. However, direct data about the heterogeneity of neoblasts in $M$. lignano is currently lacking, and more research is needed to characterize the different types of neoblasts, unravel differentiation lineages, and develop better markers for different types of somatic neoblasts. The recently developed transgenesis methods represent a convenient tool for such studies and will be discussed below.

\section{Genomic tools and resources}

Whenever faced with choosing a suitable model organism for a particular research question, scientists look at the available techniques that are established for that model. These techniques should be specific and relatively easy to perform. In case of $M$. lignano, in situ hybridization (ISH) and RNA interference (RNAi) 
are well established and widely used in the community. ISH uses a standard protocol, previously established in planarians and is a powerful method for showing expression patterns of selected genes, although it is quite laborious and suboptimal for genes with low expression (Pfister et al., 2007). RNAi is performed by simple soaking of the animals in double stranded RNA solution (Pfister et al., 2008). It is relatively easy to do but requires changing the solution on a daily basis. Both methods have a rather low throughput but can be used as screening methods and are essential techniques for a wide range of research questions in $M$. lignano (De Mulder et al., 2009; Sekii et al., 2009). However, it is the simple and robust method for generating transgenic animals that makes $M$. lignano to stand out and gives it a substantial advantage over planarian model organisms. The worms lay relatively large (100 microns in diameter), single-cell fertilized eggs that can be easily picked using plastic pickers and are a perfect material for microinjections. These eggs provide a very convenient route for delivering biologically active materials, such as RNA, DNA, proteins or chemicals directly into the organism. Recent results show that injecting simple double stranded DNA fragments can result in their integration into the genome and the establishment of stable transgenic lines that can express fluorescent protein in the tissues of interest (Wudarski et al., 2017). Because of the transparency of the worm, these marker proteins can be easily visualized by the use of light-, fluorescent-light or confocal microscopy on both fixed or live samples (Fig. 3) (Lengerer et al., 2016; Wudarski et al., 2017). Additionally, thanks to the extensive efforts of several research groups, a wealth of electron microscopy data exists (Fig. 2B) that provides a reliable source of morphological information for anyone willing to start working with these flatworms (Bode et al., 2006; Salvenmoser et al., 2010; Hoffmann et al., 2016; Grudniewska et al., 2018). Even though to date there are no reports about the use of more controllable genome manipulation technologies, such as transposons, integrases or the CRISPR/Cas9 system, based on the results of random integration of microinjected DNA one might expect these methods to be developed in the near future.

In the era of advanced molecular biology, having a sequenced and annotated genome is one of the key features a model organism must have. Sequencing of the genome of $M$. lignano was one of the key projects initiated by the Macrostomum community, which resulted in an early assembly based on PacBio sequencing data (Wasik et al., 2015), and later on was substantially improved by the addition of 454 and Illumina sequencing data and the use of the latest genome assembly algorithms (Koren et al., 2017). The size of the current $M$. lignanogenome assembly Mlig_3_7_DV1, which is based on the widely used DV1 line, is $760 \mathrm{MB}$, and corresponds to the experimentally measured genome size for this line. The N50 contig and scaffold sizes of the assembly are $215.2 \mathrm{~Kb}$ and $245.9 \mathrm{~Kb}$ respectively (Wudarski et al., 2017). While further improvement of the genome assembly contiguity is desirable, the current version already provides sufficient information for the majority of research questions.

To make full use of a genome assembly, it requires a detailed gene and repeat annotation. Therefore, substantial efforts were dedicated to annotate the genome using a large

\section{A}

set of RNA-seq data (Grudniewska et al., 2016; Wudarski et al., 2017; Grudniewska et al., 2018). The resulting genome-guided transcriptome assembly Mlig_RNA_3_7_DV1 is 98.1\% complete as measured by the Benchmarking Universal Single-Copy Orthologs (Simão et al., 2015), with only 3 missing and 3 fragmented genes. It incorporates the expression data from RNA-seq libraries generated using various approaches, such as strand-specific polyA-enriched and RiboMinus-depleted Illumina libraries and 5'-enriched RAMPAGE libraries, which can provide important additional information regarding expression levels, transcription start sites, transcription terminators and trans-splicing (Wudarski et al., 2017). All of the abovementioned data are visualized using UCSC genome browser software and are publicly available (http:// gb.macgenome.org). Additionally, a database of genes enriched in the proliferating neoblasts and germline cells are also available in the open access form (http://neoblast.macgenome.org). These
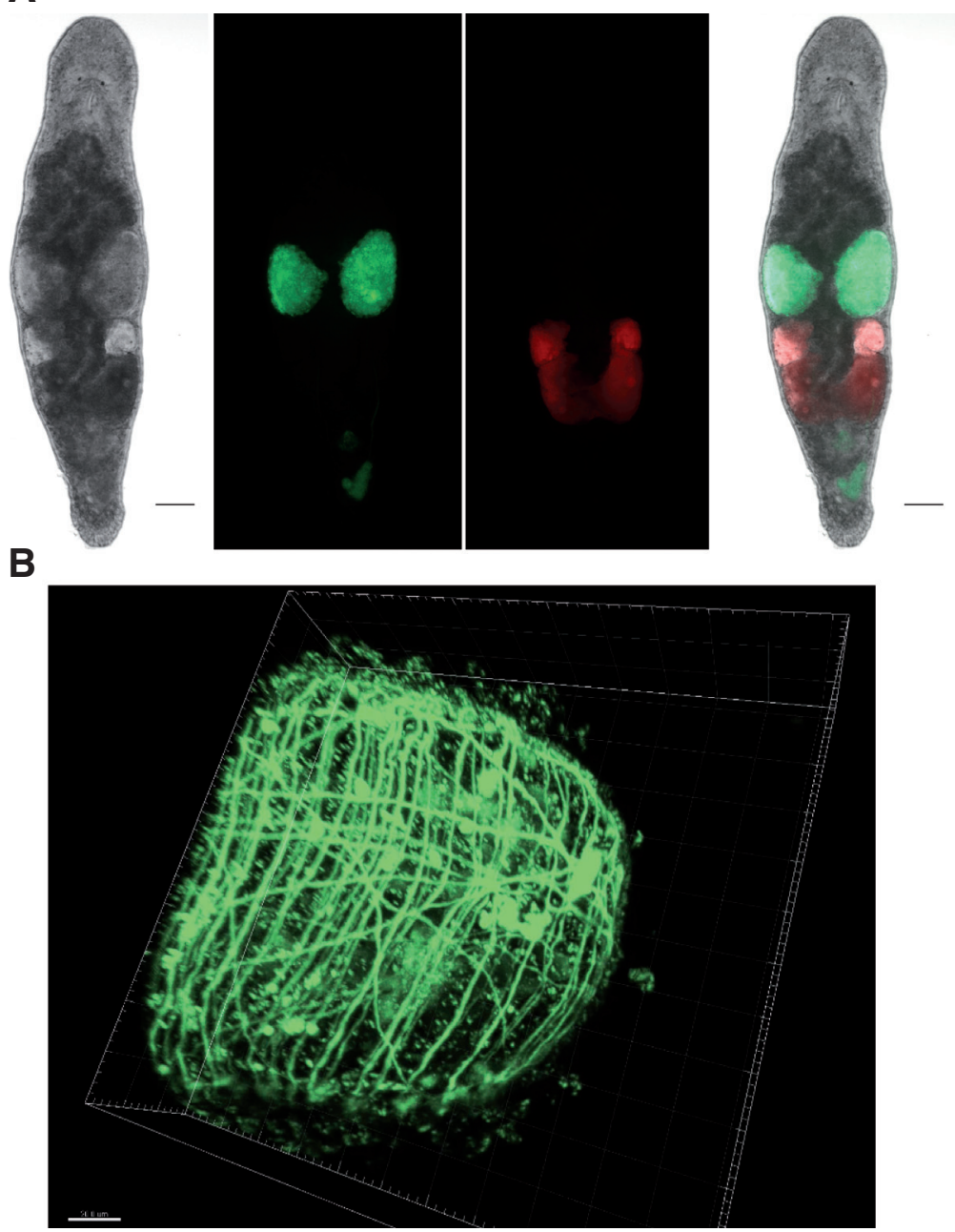

Fig. 3. Examples of tissue-specific transgenes in M. lignano. (A) Transgenic M. lignano animal from line NL24 (Wudarski et al., 2017), where ELAV promoter drives the expression of $m$ NeonGreen in the testes, and spermatozoa located in the vas deferens and seminal vesicle (shown in green), and CABP7 promoter drives the expression of mScarlet in ovaries and developing eggs (shown in red). (B) 3D visualization of confocal Z-stack image of the tail of a transgenic worm from line NL9 (Wudarski et al., 2017) expressing GFP under the muscle specific MYH promoter. 
resources were used to select several tissue-specific genes and promoters and proved to be highly reliable for ISH, RNAi and transgenic experiments (Grudniewska et al., 2016; Wudarski et al., 2017; Grudniewska et al., 2018).

\section{Research questions}

The availability of a broad set of genomic tools and resources provides a solid base for further detailed characterization of $M$. lignano, and gives the necessary means to address some of the pressing biological questions. $M$. lignano is becoming a versatile model organism and can be used in various research fields as main or supplementary choice. Here we focus on several research directions, where, in our opinion, $M$. lignano can be a particularly suitable model.

\section{Stem cells and regeneration}

The most prominent and best recognizable field of research connected to flatworms is the one regarding stem cells and regeneration. As mentioned before, the source of the astonishing regeneration capabilities of flatworms is a population of stem cells called neoblasts. These cells have been, and still are, extensively studied by various research groups. In 2011 the definitive proof of neoblast pluripotency has been demonstrated. In an elegant experiment using single cell transplantation in Schmidtea mediterranea, scientists showed that a single neoblast can restitute the regeneration ability of an otherwise regeneration incapable worm (Wagner etal., 2014). Additional studies using this model provided the first insight in the embryonic origin of neoblasts (Davies et al., 2017) and the heterogeneity of the adult neoblast population, by means of single cell transcriptomics (Molinaro and Pearson, 2016; Zhu et al., 2016). Despite this progress, we are still far from fully understanding the biology of these fascinating cells. In a recent attempt to characterize neoblasts more accurately in $M$. lignano, Grudniewska and Mouton et al., (2016) performed a molecular characterization of all of the proliferating cells in the worm. This was achieved by generating two transcriptomes of proliferating cells: the first one based on worms devoid of neoblasts through irradiation, and the second approach based on FACS selection. As a result, a list of neoblast stringent candidate genes was composed, which can help to overcome one of the major problems that still persists in the field: the lack of efficient tagging and tracking of neoblasts. This is also the point where the main advantage of $M$. lignano becomes most relevant. Having efficient ways for generating transgenic animals and, with the advent of CRISPR/ Cas9 technology, tagging neoblasts or using the FUCCI system (Sakaue-Sawano et al., 2008; Komor et al., 2016) to track their fate during regeneration would be a milestone in the process of characterizing different cell lineages and understanding the details of the differentiation of these cells.

\section{Ageing and rejuvenation}

The concept of tissue rejuvenation during regeneration, and the consequent potential immortality are long-standing hypotheses in the field of flatworm biology (Child, 1915; Haranghy and Balázs, 1964; Egger, 2008; Tan et al., 2012; Valenzano et al., 2017). $M$. lignano represents a fascinating model to study connections between stem cells, ageing and regeneration (Mouton, Willems, Braeckman, et al., 2009). In contrast to asexual planarians, which reproduce by fission and are considered immortal, and therefore have their own value for ageing research (Austad, 2009; Valenzano et al., 2017), M. lignano does age, albeit much slower than e.g. C. elegans or flies (Mouton, Willems, Braeckman, et al., 2009; Mouton, Willems, Back, et al., 2009).

Recently, a study was performed in which different characteristics such as survival, morphology, fertility, and gene expression were studied as a function of age in 3 regenerative conditions: intact worms, worms which regenerated their body once, and worms which regenerated their body multiple times (Mouton et al., 2018). Interestingly, the used inbred DV1 strain appeared to live substantially longer than the previously used wild type strain. Although phenotypic signs of ageing were observed, regenerative abilities were not decreased with advancing age, even in 26 months old animals that had their body amputated and regenerated repeatedly for 12 times. At the same time, the study demonstrated that single and multiple whole-body regeneration does not result in rejuvenation of $M$. lignano (Mouton et al., 2018), supporting the hypothesis that rejuvenation might be limited to asexual species (Tan et al., 2012). The detailed analysis of the RNA sequencing data revealed significant upregulation for somatic neoblast transcripts in old animals, including genes known to be essential for neoblast functionality, such as PIWIL1, DDX39B, CDK1, RRM1, and H2AFV (Grudniewska et al., 2016). In addition, several genes with known beneficial effects on lifespan when overexpressed in mice and $C$. elegans are naturally upregulated with age in $M$. lignano. Taken together, the gene expression data suggest that $M$. lignano evolved molecular mechanisms to offset negative consequences of ageing (Mouton et al., 2018). It will be interesting to further study $M$. lignano genes with age-specific expression patterns e. g. by means of genetic engineering in the context of other model organisms, which represents a promising research direction to explore anti-ageing strategies (Sagi and Kim, 2012).

\section{Genome maintenance and chromosome evolution}

Precise and faithful replication, preservation and damage repair of DNA are the key points in the maintenance of the genome of an organism. Any source of damage, such as polymerase errors, radiation, chemicals, $\mathrm{pH}$, temperature, or any other stress can push the system off balance and become fatal to the cell. Fortunately, cells have many ways to deal with stress conditions, such as DNA damage response and heat shock response pathways, that help keeping their key molecules intact. Studying these mechanisms is important not only from general biological perspective, but can also lead to major advancements in fields like cancer biology and medicine (Hoeijmakers, 2001; Hasty, 2003). Cancer research is one of the most highly financed branches of science but despite the enormous efforts put into deciphering the whole process of cancer, we are still unable to fully characterize it (Eckhouse et al., 2008; Cairns and Mak, 2016). Like with most fields in science, choosing an appropriate model organism is dictated by the type of biological question and the characteristics of the potential model. To date, there have been no reports on naturally occurring cancer in $M$. lignano, despite its high cellular proliferation rate. The worm is also highly resistant to external sources of DNA damage, such as ionizing radiation, being able to survive up to 210 Gy of $\gamma$-radiation, compared to just a few Gy in mammals (De Mulder et al., 2010; Grudniewska et al., 2016). Efficient DNA protection and/or repair machinery must underlie 


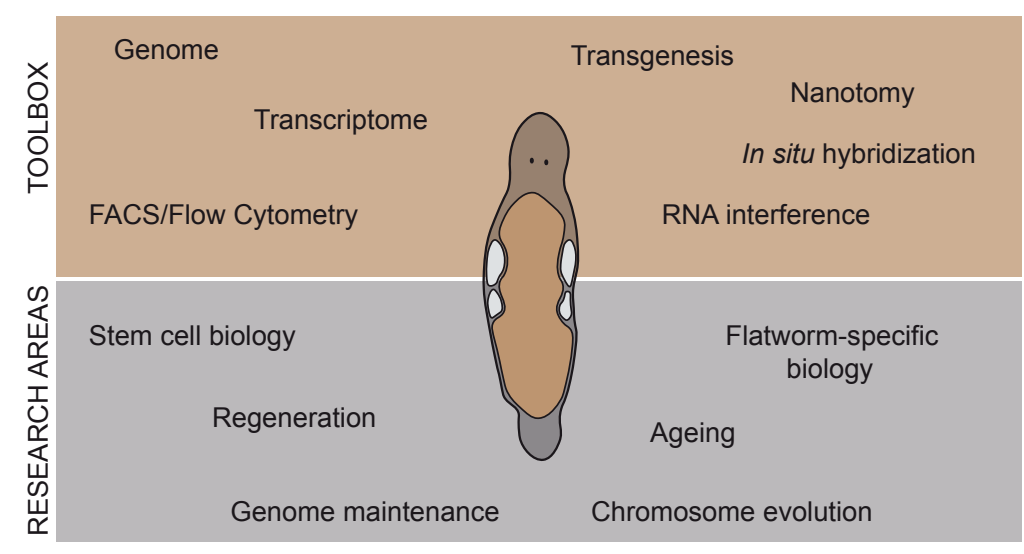

Fig. 4. Experimental potential of Macrostomum lignano. Summary of experimental tools and resources available for $\mathrm{M}$. lignano and some of the research areas where this model has large potential.

this remarkable resistance of the animal to DNA damage, and investigating its molecular mechanisms holds a great promise.

Furthermore, it was shown recently that several species of Macrostomum undergo chromosomal rearrangements and partial genome duplications (Zadesenets et al., 2016; Zadesenets et al., 2017), which adds to the potential of M. lignano as a model organism for research on genome and chromosome evolution, genome maintenance and cancer.

\section{Flatworm-specific biology}

Flatworms are an object of scientific research for more than a hundred years. The first experiments were done on planarians and documented by Harriet Randolph and Thomas H. Morgan (Randolph, 1897; Morgan, 1898). Platyhelminthes are definitely a great and appealing model when studying regeneration. It is not, however, the only field where understanding flatworm biology can be important and beneficial. For example, in the case of Macrostomum we can see a very special ability of adhering to various surfaces (Lengerer et al., 2016). This ability is even more astonishing when we consider the fact that the worms can not only attach but also detach at will, which is a very rare ability in the animal kingdom, and a detailed understanding of this process might help us advance even the field of engineering. Another example is the research performed on Neodermata, a taxa of obligatory parasitic flatworms, such as tapeworms and blood flukes, which are one of the major focuses of health-related studies performed in flatworms. However, difficulties in culturing these parasites strongly hamper the progress in the field. Having a free-living flatworm model which is easy-to-work with can substantially speed up the progress in the field of parasitic flatworm biology. $M$. lignano is a suitable model for these studies, with the availability of transgenic techniques as the major point in its favor.

To identify therapeutic gene targets without side-effects on human biology, an attractive approach is to focus on genes conserved in flatworms but not in human. Moreover, studying flatworm-specific genes is essential for understanding flatworm biology. While molecular flatworm research traditionally focuses on broadly conserved genes, including conservation in human, two recent papers illustrated the importance of the flatworm-specific approach. The first study, describing gene expression during tail regeneration, identified three novel previously unannotated Mlig-stylet genes, which are required for the formation of the male copulatory apparatus (Lengerer et al., 2018). The second study focused on a previously unannotated flatworm-specific gene Mlig-sperm1, which is part of a novel gene family, and is specifically expressed in the testes and required for producing healthy spermatozoa, and consequently, the fertility of the worms (Grudniewska et al., 2018). In conclusion, Macrostomum research is demonstrating the importance of studying flatworm-specific biology. This novel approach has the potential to impact different fundamental, but also applied research fields.

\section{Concluding remarks}

Free-living flatworms are mainly known for their regenerative capacity and represent powerful models for a broad range of research questions related to stem cell biology and regeneration. While being a rather novel flatworm model, the species Macrostomum lignano has high experimental potential due to a combination of interesting and convenient biological properties and the recent progress in developing genomic tools and resources, including transgenesis (Fig. 4). The availability of transgenesis methods in particular might make $M$. lignano the future flatworm model of choice for in depth molecular studies on stem cells and regeneration, but also expand its use into other fields of research, such as cancer, genome maintenance and ageing.

\section{Acknowledgements}

This work was supported by the European Research Council (ERC Starting Grant "MacModel”, grant no. 310765) to E.B.

\section{References}

AUSTAD SN (2009). Is there a role for new invertebrate models for aging research? Journals Gerontol - Ser A Biol Sci Med Sci 64: 192-194.

BAGUÑAJ (2012). The planarian neoblast: the rambling history of its origin and some current black boxes. Int J Dev Biol 56: 19-37.

BELY AE, NYBERG KG (2010). Evolution of animal regeneration: re-emergence of a field. Trends Ecol Evol 25: 161-170.

BODE A, SALVENMOSER W, NIMETH K, MAHLKNECHT M, ADAMSKI Z, RIEGER RM, PETER R, LADURNER P (2006). Immunogold-labeled S-phase neoblasts, total neoblast number, their distribution, and evidence for arrested neoblasts in Macrostomum lignano (Platyhelminthes, Rhabditophora). Cell Tissue Res 325: 577-587.

BOSCH TCG (2007). Why polyps regenerate and we don't: Towards a cellular and molecular framework for Hydra regeneration. Dev Biol 303: 421-433.

CAIRNS RA, MAK TW (2016). The current state of cancer metabolism. Nat Publ Gr 16: 613-614.

CARDONAA, HARTENSTEIN V, ROMEROR (2006). Early embryogenesis of planaria: a cryptic larva feeding on maternal resources. Dev Genes Evol 216: 667-681.

CARDONA A, HARTENSTEIN V, ROMERO R (2005). The embryonic development of the triclad Schmidtea polychroa. Dev Genes Evol 215: 109-131.

CHILD CM (1915). Senescence and Rejuvenescence. The University of Chicago Press, Chicago.

DAVIES EL, LEI K, SEIDEL CW, KROESEN AE, MCKINNEY SA, GUO L, ROBB SMC, ROSS EJ, GOTTING K, ALVARADO AS (2017). Embryonic origin of adult stem cells required for tissue homeostasis and regeneration. eLife 6: e21052.

DE MULDER K, KUALES G, PFISTER D, EGGER B, SEPPI T, EICHBERGER P, BORGONIE G, LADURNERP (2010). Potential of Macrostomum lignano to recover from gamma-ray irradiation. Cell Tissue Res 339: 527-542. 
DE MULDER K, PFISTER D, KUALES G, EGGER B, SALVENMOSER W, WILLEMS M, STEGER J, FAUSTER K, MICURA R, BORGONIE G, LADURNER P (2009). Stem cells are differentially regulated during development, regeneration and homeostasis in flatworms. Dev Biol 334: 198-212.

ECKHOUSE S, LEWISON G, SULLIVAN R (2008). Trends in the global funding and activity of cancer research. Mol Oncol 2: 20-32.

EGGER B (2008). Regeneration: Rewarding, but potentially risky. Birth Defects Res Part C - Embryo Today Rev 84: 257-264.

EGGER B, GSCHWENTNER R, RIEGER R (2007). Free-living flatworms under the knife: Past and present. Dev Genes Evol 217: 89-104.

EGGER B, LADURNER P, NIMETH K, GSCHWENTNER R, RIEGER R (2006). The regeneration capacity of the flatworm Macrostomum lignano - On repeated regeneration, rejuvenation, and the minimal size needed for regeneration. Dev Genes Evol 216: 565-577.

EGGER B, LAPRAZ F, TOMICZEK B, MÜLLER S, DESSIMOZ C, GIRSTMAIR J, ŠKUNCA N, RAWLINSON KA, CAMERON CB, BELI E, TODARO MA, GAMMOUDI M, NOREÑA C, TELFORD MJ (2015). A Transcriptomic-Phylogenomic Analysis of the Evolutionary Relationships of Flatworms. Curr Biol25: 1347-1353.

GIANNAKARA A, SCHÄRER L, RAMM SA (2016). Sperm competition-induced plasticity in the speed of spermatogenesis. BMC Evol Biol 16: 60.

GRUDNIEWSKAM, MOUTON S, GRELLING M, WOLTERSAHG, KUIPERS J, GIEPMANS BNG, BEREZIKOV E (2018). A novel flatworm-specific gene implicated in reproduction in Macrostomum lignano. Sci Rep 8: 3192.

GRUDNIEWSKA M, MOUTON S, SIMANOV D, BELTMAN F, GRELLING M, DE MULDER K, ARINDRARTO W, WEISSERT PM, VAN DER ELST S, BEREZIKOV E (2016). Transcriptional signatures of somatic neoblasts and germline cells in Macrostomum lignano. eLife 5: e20607.

HARANGHY L, BALÁZS A (1964). Ageing and rejuvenation in planarians. Exp Gerontol 1: 77-91.

HASTY P (2003). Aging and Genome Maintenance: Lessons from the Mouse? Science (80-) 299: 1355-1359.

HOEIJMAKERS JHJ (2001). Genome maintenance mechanisms for preventing cancer. Nature 411: 366-374.

HOFFMANN RF, MOSHKIN YM, MOUTON S, GRZESCHIK NA, KALICHARAN RD, KUIPERS J, WOLTERS AHG, NISHIDA K, ROMASHCHENKO A V., POSTBERG J, LIPPS H, BEREZIKOV E, SIBON OCM, GIEPMANS BNG, LANSDORP PM (2016). Guanine quadruplex structures localize to heterochromatin. Nucleic Acids Res 44: 152-163.

KOMOR AC, BADRAN AH, LIU DR (2016). CRISPR-Based Technologies for the Manipulation of Eukaryotic Genomes. Cell 168: 1-17.

KOREN S, WALENZ BP, BERLIN K, MILLER JR, BERGMAN NH, PHILLIPPY AM (2017). Canu: scalable and accurate long-read assembly via adaptive $\mathrm{k}$-mer weighting and repeat separation. Genome Res 27: 722-736.

LADURNER P, EGGER B, MULDER K De, PFISTER D, KUALES G, SALVENMOSER W, SCHÄRER L (2008). The Stem Cell System of the Basal Flatworm Macrostomum lignano. In Stem cells: from Hydra to man Bosh, Th.C.G., Berlin - Heidelberg - New York, pp. 75-94.

LADURNER P, RIEGER R, BAGUÑÀ J (2000). Spatial distribution and differentiation potential of stem cells in hatchlings and adults in the marine platyhelminth macrostomum sp.: a bromodeoxyuridine analysis. Dev Biol 226: 231-241.

LADURNER P, SCHÄRER L, SALVENMOSER W, RIEGER RM (2005). A new model organism among the lower Bilateria and the use of digital microscopy in taxonomy of meiobenthic Platyhelminthes: Macrostomum lignano, n. sp. (Rhabditophora, Macrostomorpha). J Zool Syst Evol Res 43: 114-126.

LAUMER CE, HEJNOL A, GIRIBET G (2015). Nuclear genomic signals of the "microturbellarian" roots of platyhelminth evolutionary innovation. eLife 4: e05503.

LENGERER B, HENNEBERT E, FLAMMANG P, SALVENMOSER W, LADURNER P (2016). Adhesive organ regeneration in Macrostomum lignano. BMCDev Bio/16:20.

LENGERER B, PJETA R, WUNDERER J, RODRIGUES M, ARBORE R, SCHÄRER L, BEREZIKOV E, HESS MW, PFALLER K, EGGER B, OBWEGESER S, SALVENMOSER W, LADURNER P (2014). Biological adhesion of the flatworm Macrostomum lignano relies on a duo-gland system and is mediated by a cell type-specific intermediate filament protein. Front Zool 11: 12.

LENGERER B, WUNDERER J, PJETA R, CARTA G, KAO D, ABOOBAKER A, BEISEL C, BEREZIKOV E, SALVENMOSER W, LADURNER P (2018). Organ specific gene expression in the regenerating tail of Macrostomum lignano. Dev Biol 433: 448-460.

LI Q, YANG H, ZHONG TP (2015). Regeneration across Metazoan Phylogeny: Lessons from Model Organisms. J Genet Genomics 42: 57-70.

LIU S-Y, SELCK C, FRIEDRICH B, LUTZ R, VILA-FARRÉ M, DAHL A, BRANDL H, LAKSHMANAPERUMALN, HENRYI, RINKJC (2013). Reactivating head regrowth in a regeneration-deficient planarian species. Nature 500: 81-84.

MARIE-ORLEACH L, JANICKE T, VIZOSO DB, DAVID P, SCHÄRER L (2016). Quantifying episodes of sexual selection: Insights from a transparent worm with fluorescent sperm. Evolution 70: 314-328.

MICHALOPOULOS GK, DEFRANCES MC (1997). Liver regeneration. Science 276: 60-66.

MOLINARO AM, PEARSON BJ (2016). In silico lineage tracing through single cell transcriptomics identifies a neural stem cell population in planarians. Genome Biol 17: 87.

MORRIS J, CARDONA A, DE MIGUEL-BONET MDM, HARTENSTEIN V (2007). Neurobiology of the basal platyhelminth Macrostomum lignano: map and digital 3D model of the juvenile brain neuropile. Dev Genes Evol 217: 569-584.

MORRIS J, LADURNER P, RIEGER R, PFISTER D, DE MIGUEL-BONET MDM, JACOBS D, HARTENSTEIN V (2006). The Macrostomum lignano EST database as a molecular resource for studying platyhelminth development and phylogeny. Dev Genes Evol 216: 695-707.

MORRIS J, NALLUR R, LADURNER P, EGGER B, RIEGER R, HARTENSTEIN $V$ (2004). The embryonic development of the flatworm Macrostomum sp. Dev Genes Evol 214: 220-239.

MOUTON S, GRUDNIEWSKA M, GLAZENBURG L, GURYEV V, BEREZIKOV E (2018). Resilience to aging in the regeneration-capable flatworm Macrostomum lignano. Aging Cell 2018: Feb 28. doi: 10.1111/acel.12739

MOUTON S, WILLEMS M, BACK P, BRAECKMAN BP, BORGONIE G (2009). Demographic analysis reveals gradual senescence in the flatworm Macrostomum lignano. Front Zool 6: 15.

MOUTON S, WILLEMS M, BRAECKMAN BP, EGGER B, LADURNER P, SCHÄRER L, BORGONIE G (2009). The free-living flatworm Macrostomum lignano: A new model organism for ageing research. Exp Gerontol 44: 243-249.

NIMETH K, LADURNER P, GSCHWENTNER R, SALVENMOSER W, RIEGER R (2002). Cell renewal and apoptosis in Macrostomum sp.[Lignano]. Cell Biol Int 26: 801-815.

NIMETH KT, EGGER B, RIEGER R, SALVENMOSER W, PETER R, GSCHWENTNER R (2007). Regeneration in Macrostomum lignano (Platyhelminthes): cellular dynamics in the neoblast stem cell system. Cell Tissue Res 327: 637-646.

NIMETH KT, MAHLKNECHT M, MEZZANATO A, PETER R, RIEGER R, LADURNER $P$ (2004). Stem cell dynamics during growth, feeding, and starvation in the basal flatworm Macrostomum sp. (Platyhelminthes). Dev Dyn 230: 91-99.

PFISTER D, DE MULDER K, HARTENSTEIN V, KUALES G, BORGONIE G, MARX F, MORRIS J, LADURNER P (2008). Flatworm stem cells and the germ line: Developmental and evolutionary implications of macvasa expression in Macrostomum lignano. Dev Biol 319: 146-159.

PFISTER D, DE MULDER K, PHILIPP I, KUALES G, HROUDA M, EICHBERGER P, BORGONIE G, HARTENSTEIN V, LADURNER P (2007). The exceptional stem cell system of Macrostomum lignano: screening for gene expression and studying cell proliferation by hydroxyurea treatment and irradiation. Front Zool 4: 9.

RIEGER R, GEHLEN M, HASZPRUNAR G, HOLMLUND M, LEGNITI A, SALVENMOSER W, TYLER S (1988). Laboratory cultures of marine Macrostomida (Turbellaria). Fortschr Zool 36: 523.

RINK JC (2013). Stem cell systems and regeneration in planaria. Dev Genes Evol 223: $67-84$.

ROSENTHAL N, BADYLAK S (2016). Regenerative medicine: today's discoveries informing the future of medical practice. NPJ Regen Med 1: 16007.

SAGI D, KIM SK (2012). An engineering approach to extending lifespan in C. elegans. PLoS Genet 8: e1002780.

SAKAUE-SAWANO A, KUROKAWA H, MORIMURA T, HANYU A, HAMA H, OSAWA H, KASHIWAGI S, FUKAMI K, MIYATA T, MIYOSHI H, IMAMURA T, OGAWA M, MASAI H, MIYAWAKI A (2008). Visualizing Spatiotemporal Dynamics of Multicellular Cell-Cycle Progression. Cell 132: 487-498.

SALVENMOSER W, EGGER B, ACHATZ JG, LADURNER P, HESS MW (2010). 
Electron microscopy of flatworms. Standard and cryo-preparation methods. Methods Cell Biol 96: 307-330.

SÁNCHEZ ALVARADO A (2000). Regeneration in the metazoans: why does it happen? Bioessays 22: 578-590.

SCHÄRER L, LADURNER P (2003). Phenotypically plastic adjustment of sex allocation in a simultaneous hermaphrodite. Proc $R$ Soc B Biol Sci 270: 935-941.

SEKII K, SALVENMOSER W, DE MULDER K, SCHARER L, LADURNER P (2009). Melav2, an elav-like gene, is essential for spermatid differentiation in the flatworm Macrostomum lignano. BMC Dev Biol 9: 62.

SIKES JM, NEWMARK PA (2013). Restoration of anterior regeneration in a planarian with limited regenerative ability. Nature 500: 77-80.

SIMANOV D, MELLAART-STRAVERI, SORMACHEVAI, BEREZIKOVE (2012). The Flatworm Macrostomum lignano Is a Powerful Model Organism for Ion Channel and Stem Cell Research. Stem Cells Int 2012: 1-10.

SIMÃO FA, WATERHOUSE RM, IOANNIDIS P, KRIVENTSEVA E V, ZDOBNOV EM (2015). BUSCO: assessing genome assembly and annotation completeness with single-copy orthologs. Bioinformatics 31: 3210-3212.

TANTCJ, RAHMANR, JABER-HIJAZIF, FELIXDA, CHENC, LOUISEJ, ABOOBAKER $A$ (2012). Telomere maintenance and telomerase activity are differentially regulated in asexual and sexual worms. Proc Natl Acad Sci USA 109: 4209-4214.

TANAKA EM, REDDIEN PW (2011). The Cellular Basis for Animal Regeneration. Dev Cell 21: 172-185.

VALENZANO DR, ABOOBAKER A, SELUANOV A, GORBUNOVA V (2017). Noncanonical aging model systems and why we need them. EMBO J 36: 959-963.

VERDOODT F, WILLEMS M, MOUTON S, DE MULDER K, BERT W, HOUTHOOFD W, SMITH J, LADURNER P (2012). Stem cells propagate their DNA by random segregation in the flatworm Macrostomum lignano. PLoS One 7: e30227.

WAGNER DE, WANG IE, REDDIEN PW, EVANS MJ, EVANS MJ, KAUFMAN MH, MARTIN GR, WAGERS AJ, SHERWOOD RI, CHRISTENSEN JL, et al., (2014).
Clonogenic Neoblasts Are Pluripotent Adult Stem Cells That Underlie Planarian Regeneration. Science 332: 811-816.

WASIK K, GURTOWSKI J, ZHOU X, RAMOS OM, DELÁS MJ, BATTISTONI G, EL DEMERDASH O, FALCIATORI I, VIZOSO DB, SMITH AD, LADURNER P, SCHÄRER L, MCCOMBIE WR, HANNON GJ, SCHATZ M (2015). Genome and transcriptome of the regeneration-competent flatworm, Macrostomum lignano. Proc Natl Acad Sci USA 112: 12462-12467.

WILLEMS M, EGGER B, WOLFF C, MOUTON S, HOUTHOOFD W, FONDERIE P, COUVREUR M, ARTOIS T, BORGONIE G (2009). Embryonic origins of hull cells in the flatworm Macrostomum lignano through cell lineage analysis: Developmental and phylogenetic implications. Dev Genes Evol 219: 409-417.

VAN WOLFSWINKEL JC, WAGNER DE, REDDIEN PW (2014). Single-cell analysis reveals functionally distinct classes within the planarian stem cell compartment. Cell Stem Cell 15: 326-339.

WUDARSKI J, SIMANOV D, USTYANTSEV K, DE MULDER K, GRELLING M, GRUDNIEWSKAM, BELTMAN F, GLAZENBURG L, DEMIRCANT, WUNDERER $J$, et al., (2017). Efficient transgenesis and annotated genome sequence of the regenerative flatworm model Macrostomum lignano. Nat Commun 8: 2120.

ZADESENETS K, ERSHOV N, BEREZIKOV E, RUBTSOV N (2017). Chromosome Evolution in the Free-Living Flatworms: First Evidence of Intrachromosomal Rearrangements in Karyotype Evolution of Macrostomum lignano (Platyhelminthes, Macrostomida). Genes 8: 298.

ZADESENETS KS, VIZOSO DB, SCHLATTERA, KONOPATSKAIA ID, BEREZIKOV E, SCHÄRER L, RUBTSOV NB, CASTIGLIA R, VIZOSO DB, SCHLATTER A, KONOPATSKAIA ID, BEREZIKOV E, SCHÄRER L, RUBTSOV NB (2016). Evidence for karyotype polymorphism in the free-living flatworm, macrostomum lignano, a model organism for evolutionary and developmental biology. PLOS One 11: e0164915.

ZHUSJ, PEARSONBJ, REDDIEN PW, TANAKAEM (2016). (Neo)blast from the past: new insights into planarian stem cell lineages. Curr Opin Genet Dev 40: 74-80. 


\section{Further Related Reading, published previously in the Int. J. Dev. Biol.}

Planaria: an animal model that integrates development, regeneration and pharmacology

Oné R. Pagán

Int. J. Dev. Biol. (2017) 61: 519-529

https://doi.org/10.1387/ijdb.160328op

Regeneration of neuronal cell types in Schmidtea mediterranea: an immunohistochemical and expression study

Susanna Fraguas, Sara Barberán, Begoña Ibarra, Linda Stöger and Francesc Cebrià

Int. J. Dev. Biol. (2012) 56: 143-153

https://doi.org/10.1387/ijdb.113428sf

Stem cells and neural signalling: the case of neoblast recruitment and plasticity in low dose X-ray treated planarians

Leonardo Rossi, Paola lacopetti and Alessandra Salvetti

Int. J. Dev. Biol. (2012) 56: 135-142

https://doi.org/10.1387/ijdb.123505lr

Stem cell protection mechanisms in planarians: the role of some heat shock genes

Maria-Emilia Isolani, Maria Conte, Paolo Deri and Renata Batistoni

Int. J. Dev. Biol. (2012) 56: 127-133

https://doi.org/10.1387/ijdb.113432mi

Global irradiation effects, stem cell genes and rare transcripts in the planarian transcriptome

Mireille Galloni

Int. J. Dev. Biol. (2012) 56: 103-116

https://doi.org/10.1387/ijdb.113455mg

Comprehensive gene expression analyses in pluripotent stem cells of a planarian, Dugesia japonica

Norito Shibata, Tetsutaro Hayashi, Ryutaro Fukumura, Junsuke Fujii, Tomomi KudomeTakamatsu, Osamu Nishimura, Syozo Sano, Fuyan Son, Nobuko Suzuki, Ryoko Araki, Masumi Abe and Kiyokazu Agata

Int. J. Dev. Biol. (2012) 56: 93-102

https://doi.org/10.1387/ijdb.113434ns

The past and present of planarians - An interview with Vittorio Gremigni Alessandra Salvetti and Leonardo Rossi

Int. J. Dev. Biol. (2012) 56: 49-52

https://doi.org/10.1387/ijdb.113453as

5 yr ISI Impact Factor $(2016)=2.421$
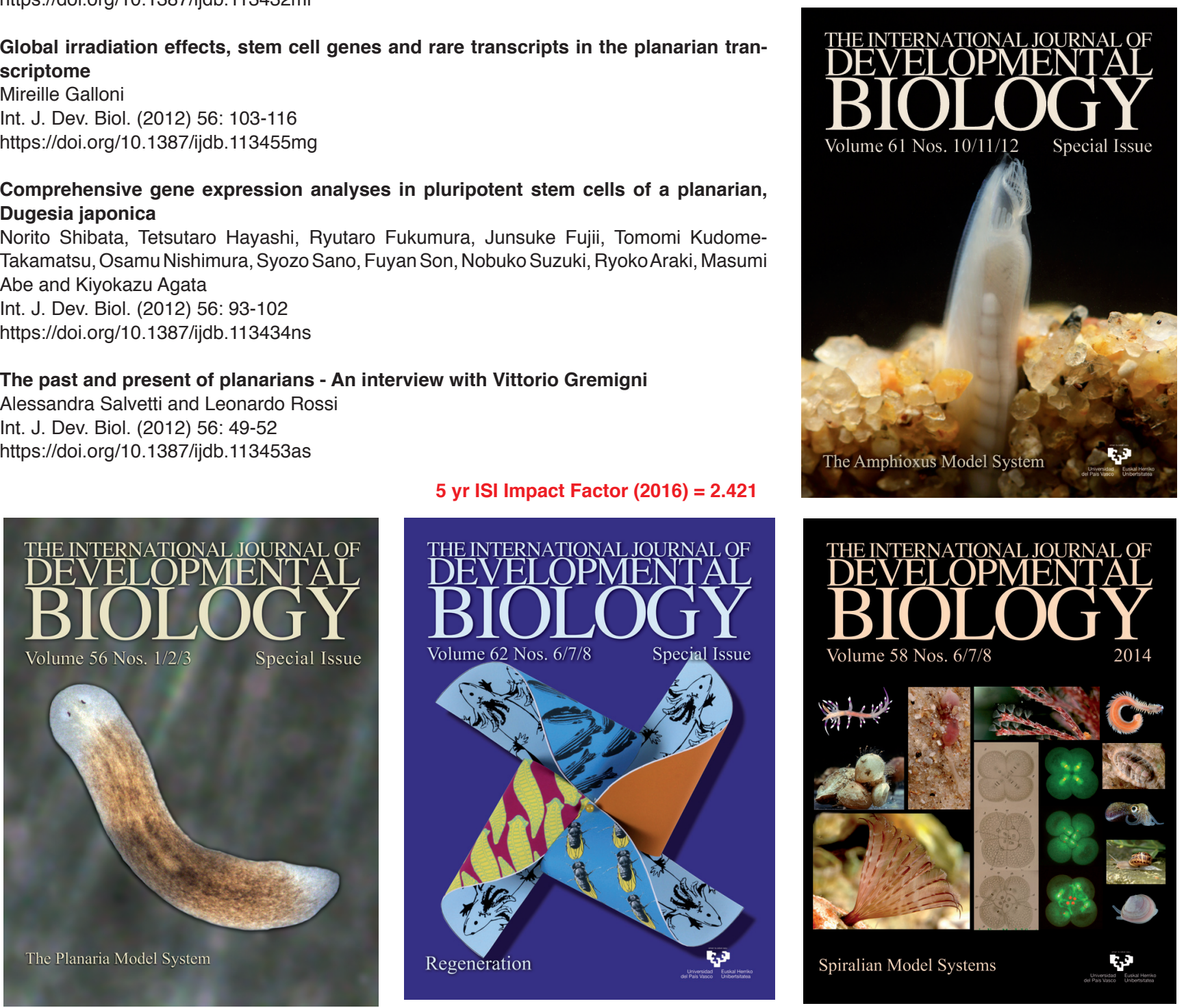